\title{
CONCEPTUAL ANALYSIS OF TEST CAR BODY WITH THE USE OF CAD SYSTEMS
}

\author{
Bartosz Moczulak $^{\mathrm{a}^{*}}$, Wojciech Miąskowski ${ }^{\mathrm{b}}$, Krzysztof Nalepa ${ }^{\mathrm{c}}$ \\ ${ }^{a}$ Faculty of Technical Sciences, University of Warmia and Mazury in Olsztyn, Poland, \\ bartosz.moczulak@uwm.edu.pl, ORCID 0000-0002-4110-0273 \\ b Faculty of Technical Sciences, University of Warmia and Mazury in Olsztyn, Poland \\ wojmek@uwm.edu.pl ORCID 0000-0001-6080-7357 \\ ${ }^{\mathrm{c}}$ Faculty of Technical Sciences, University of Warmia and Mazury in Olsztyn, Poland, \\ nalepka@uwm.edu.pl ORCID 0000-0002-0399-8385
}

"Corresponding author: e-mail: bartosz.moczulak@uwm.edu.pl

\begin{tabular}{l}
\hline ARTICLE INFO \\
\hline Article history: \\
Received: November 2019 \\
Received in the revised form: \\
December 2019 \\
Accepted: December 2019 \\
\hline Key words: \\
analysis \\
car body \\
CAD systems \\
test car \\
\\
\hline
\end{tabular}

ABSTRACT
The article presents structural specifications and conceptual analysis of
the test car body equipped with a hybrid power transmission system.
The test car is constructed by students of the Faculty of Technical Sci-
ences of the University of Warmia and Mazury in Olsztyn. Works ded-
icated to designing and construction of a car body aim at the increase
of safety and improvement of aesthetics of the constructed vehicle with
simultaneous maintenance of its operational and test functionality. The
article presents a simplified analysis of the distribution of pressure
around the body for several suggested concepts and selected technolo-
gies of production of the test car body. The paper presents results of
computer simulations, of the pressure distribution and the remaining
aspects of assessment of the car body functionality.

\section{Introduction}

The idea of construction of the test vehicle consists in reduction of emission of hazardous fumes to atmosphere through additional supply of the combustion engine with the hydro oxygen mixture (Fig. 1).

Due to adaptative and research works, the engine compartment is behind a driver (fig. 1). It is dictated by simplification of the vehicle construction and safety reasons (Miąskowski et al., 2012; Miąskowski et al., 2017).

A car body has many functions. It covers mechanisms installed in a vehicle, separates engine/passenger/goods compartments and has aesthetic functions (Orzełowski, 1969; Hinz and Lewkowicz, 2015). By dividing the structure of a vehicle into specific sectors, a car body also plays a safety function against explosion of the engine and protection for passengers; life and health. Car bodies may be divided also with regard to the structure type: frame and self-supporting. In frame structures (non-supporting car bodies) a car body is a basic carrying 
element of a vehicle. The main task of the frame car body is ensuring relevant stiffness (Budzik et al., 2009; Bilewski et al., 2013). In case of cars, an engine, elements of chassis, complete car body and e.g. a load bed is mounted (Zieliński, 2008).

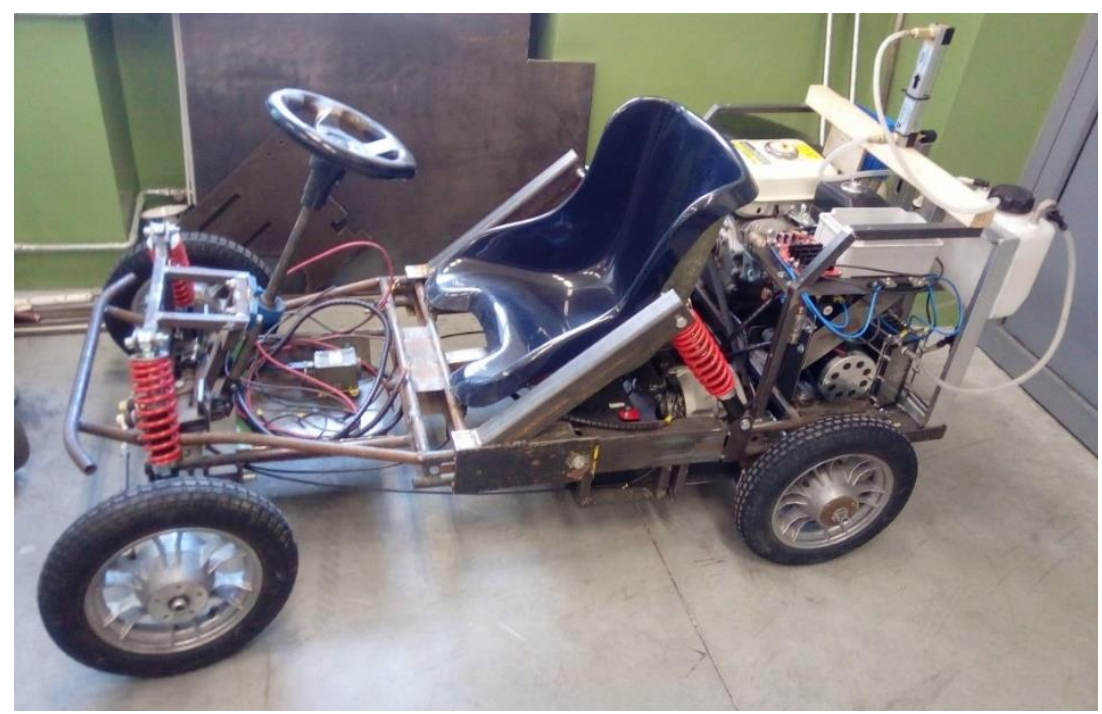

Figure 1. View of the test vehicle without car body

In self-supporting car bodies, a supporting element is the structure of the car body itself which is a bearing beam, thanks to which a division into a frame chassis and non-supporting car body placed on it was eliminated (e.g. trucks). The use of self-supporting car bodies caused a considerable reduction of mass of vehicles and their crashworthiness. An intermediary structure is a half-supporting car body where the car body is assembled stiffly to the light frame (Lach et al., 2015; Zieliński, 2008).

\section{Structural assumptions}

The aim of the works on the structure of a car body is to raise the level of safety of people which operate the test car and a general aesthetics of the vehicle, maintaining at the same time a possibility to carry out operational and maintenance activities with main mechanisms of the vehicle.

Structural assumptions made for design works on the construction of the car body of the test car:

- Due to the nature of the performed works, it was decided to make an open structure;

- No roof structure in the car results from the need of frequent leaving of the passenger part to carry out test works (registration of phenomena that take place) and performance of tests and service and operational activities;

- A structure of the car body will be assembled to the existing structure of the car body; 
Conceptual analysis of test car...

- A car body will play a protective function against a possible explosion in the engine compartment;

- It is planned to mount an additional protective coat from the sheet metal that protects against the effects of explosion;

- The car body will protect components against outside damage;

- It will reduce aerodynamic resistance during driving;

- The structure of the car body should enable access to particular components and mechanisms installed in the car and increase aesthetic values of the test car.

Analysis of the external shape of the structure of the car body, available production capacities were taken into consideration. These were: a structure of the car body made of sheet metal using technologies of bending, cutting, and welding; a structure of the car body using lamination of polyester-glass elements, making the car body with the use of 3D printing technology. The car body made of sheet metal would protect internal mechanism against damage in the best possible way; however, the total mass of the vehicle will increase. Additional difficulty is making an aerodynamic shape that ensures a reduced index of aerodynamic resistance of air (Guilmineau, 2008). A technology that uses manual lamination is a satisfactory solution in production of a small number of elements, where a high quality and precision of making is not required. Due to lamination, objects with any shapes can be manufactured; however, their impulse and fatigue strength is extremely limited. A technology of production of polyester and glass laminate composites requires previous preparation of a form. Production of a car body due to the use of 3D technology will enable to obtain a previously assumed shape in an almost wasteless manner. A ready object would be made with a faithful reproduction of the 3D model with maintenance of an aerodynamic shape. The 3D print technology provides great possibilities of shaping ready surfaces; however, anisotropy of printed objects is a limitation to this method (Budzik et al., 2009). The car body manufactured in such a way would have a light mass and an elevated level of aesthetics of production; however, its impact resistance will depend on the selection of printing and material parameters.

\section{Conceptual analysis}

Based on structural assumptions and arrangements concerning functionality of the structure of the car body, four concepts of the car body model for the test car were suggested. 3D models were made in SolidWorks environment.

\section{Concept 1}

The concept assumes production of the test car body based on simple raw shapes (Fig.2). A carcass of the vehicle along with all mechanisms would be located inside the car body. A front end of the car body keeps its shape at the whole width of the vehicle. Therefore, driver's legs are hidden under the car body. The "engine" space was covered with sheet metal which results directly from the structure of assembly of equipment. The rear part of the car body ends with a flat, reclining surface without the use of treatments that would mitigate the air stream turbulence. Concept 1 is technologically adjusted to production with all the abovementioned methods. Using relevant ergonomic techniques, i.e. divisibility of the structure that enables access to important mechanisms, basic requirements for the car body were maintained. 


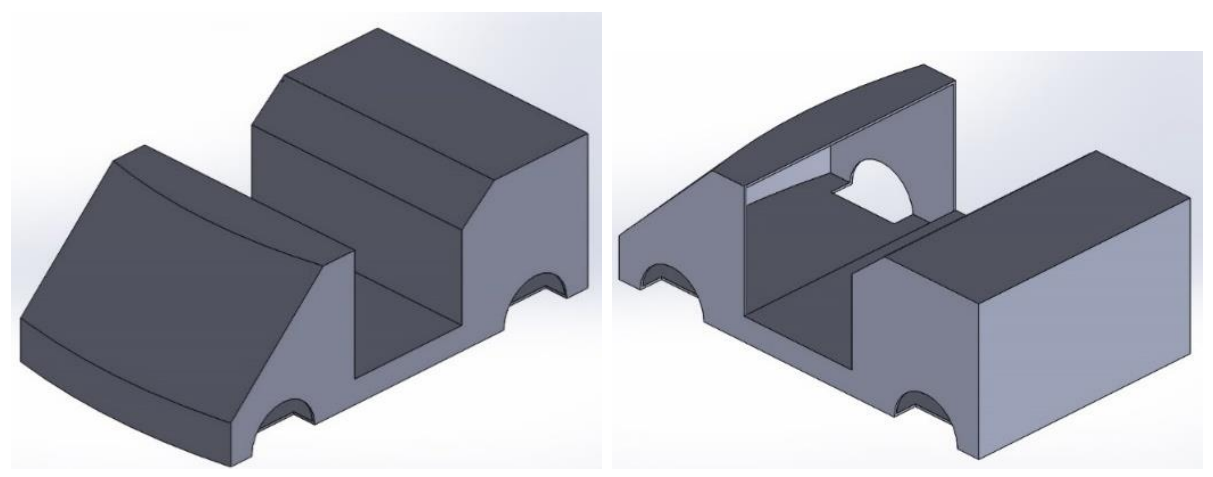

Figure 2. Simplified view of the car body concept in version no. 1

\section{Concept 2}

In concept 2 decision was to change the shape of the front part of the car body which would result in reduction of aerodynamic resistance and increase of aesthetic values of the structure (Fig.3). In the rear part, it was suggested to use spoilers and bending of edges which will reduce turbulence of the air stream behind the vehicle during its motion (Song et al., 2011). In the concept 2 the use of bending and cutting technologies for maintaining an aerodynamic shape will be more labour consuming.
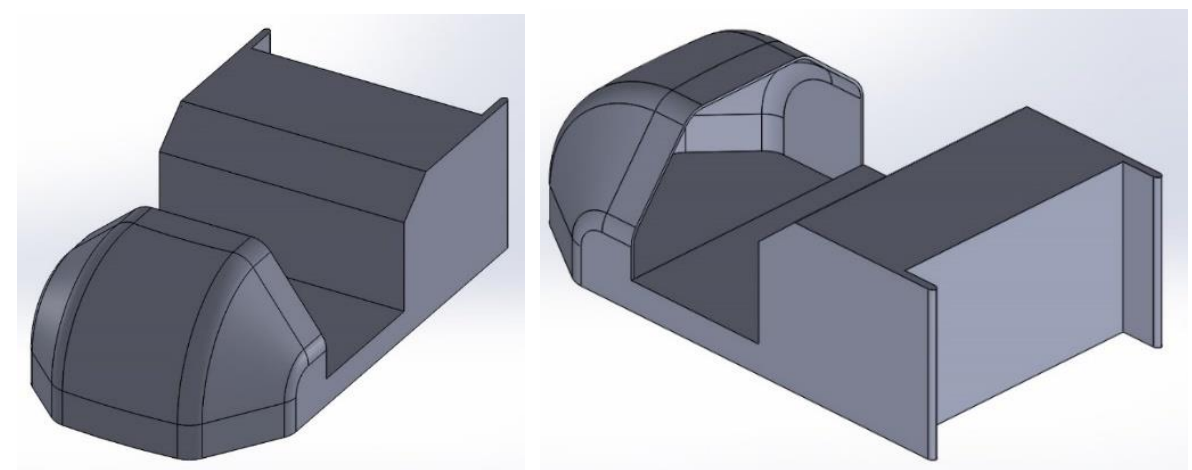

Figure 3. Simplified view of the car body concept in version no. 2

\section{Concept 3}

In concept 3 an appearance and shape of the front part was completely changed, and the steering system was shielded limiting thus the impact of the wind on a driver. It will be required to use additional mudguards in the front and rear axis (Fig.4). The cover of the engine chamber will also use the bending of edges to reduce air stream turbulences. Air inlets were 
presented in the cover in the side walls to improve thermal exchange of an engine with the surrounding. Air inlets are designed in the final version and they are available in each concept, with the same functions. Due to the methods of lamination of the car body and 3D print, with maintenance of the previously mentioned principles of division of the car body surface, they are effective methods.

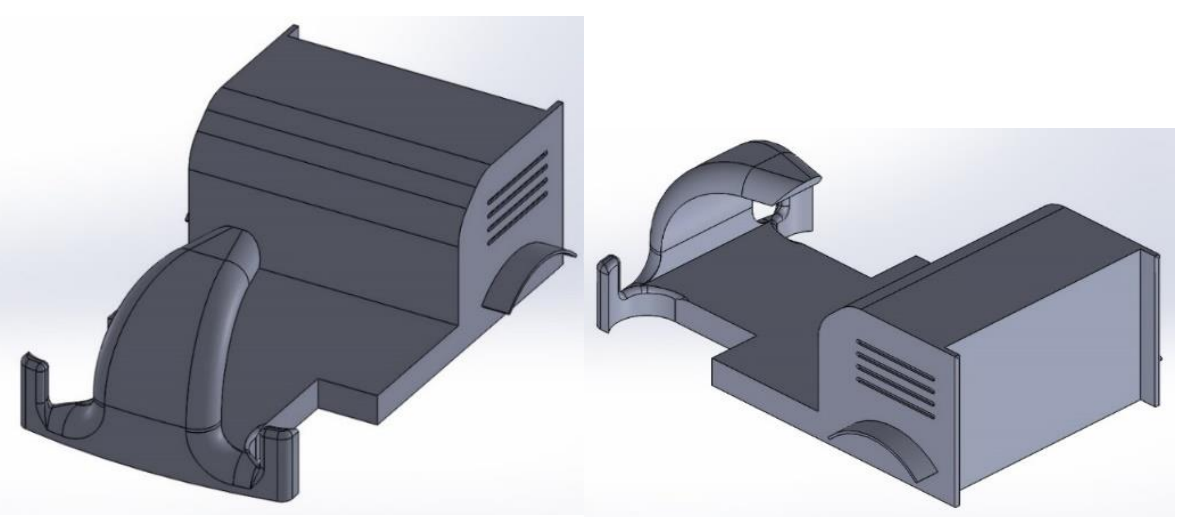

Figure 4. Simplified view of the car body concept in version no. 3

\section{Concept 4}

In concept 4 , it was decided to extend the front end of the car body to reduce aerodynamic resistance and improvement of the air flow around the vehicle (Fig. 5) at the expense of the lower manoeuvrability. Driver's legs, as in concept 1, are hidden under the surface of the car body. The car body presented in concept 4 can be made with all the above-mentioned methods.
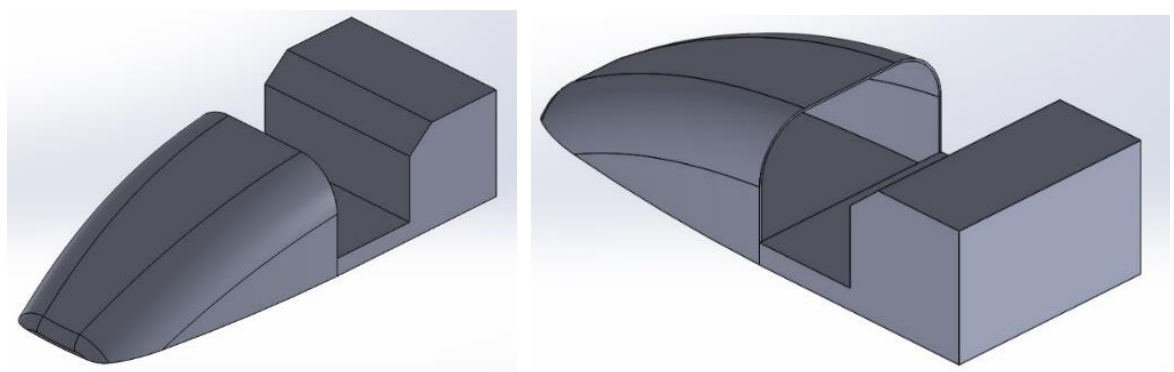

Figure 5. Simplified view of the car body concept in version no. 4

The above concepts were also analysed on account of distribution of pressure in the vehicle symmetry plane and air trajectory around the car body model using for this purpose SolidWorks Flow Simulation software. The following boundary conditions were assumed: ambient pressure $101325 \mathrm{~Pa}$, ambient temperature $20^{\circ} \mathrm{C}$, maximum speed $50 \mathrm{~km} \cdot \mathrm{h}^{-1}$ and 
global calculation grid. A numerical analysis of flow for each concept was made in two variants - with the use of the front windscreen and without a windscreen. The variant with the windscreen shows smaller disorders of flow in the driver's space, therefore, results of simulations of the model with a windscreen were presented.

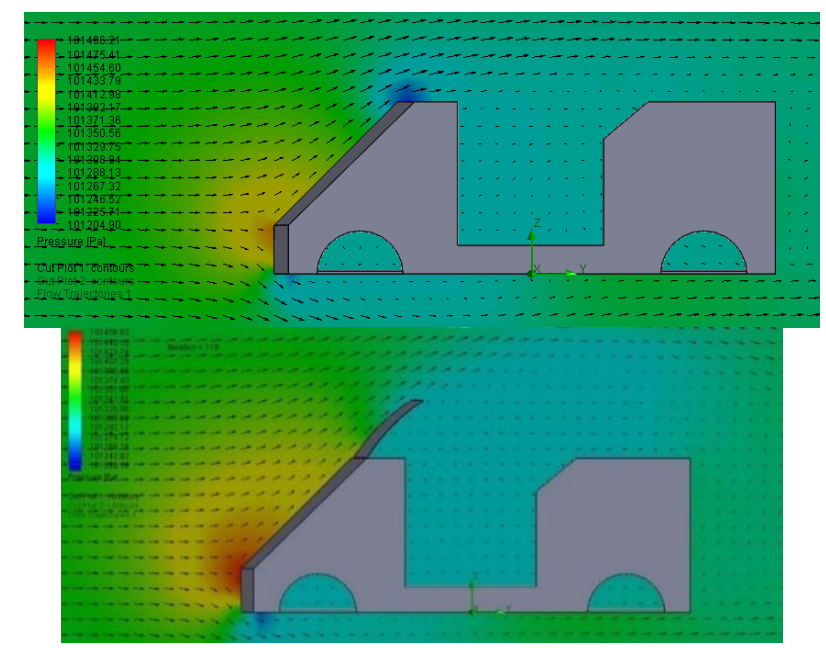

Figure 6. Distribution of pressure along the car body line concept 1

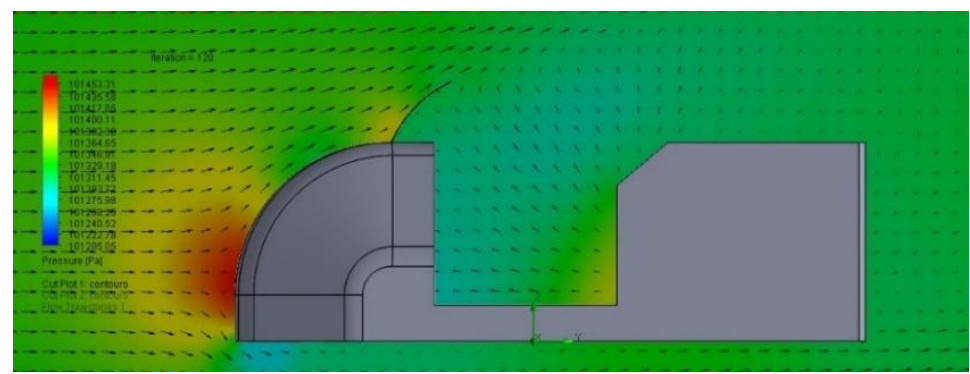

Figure 7. Distribution of pressure along the car body line concept 2

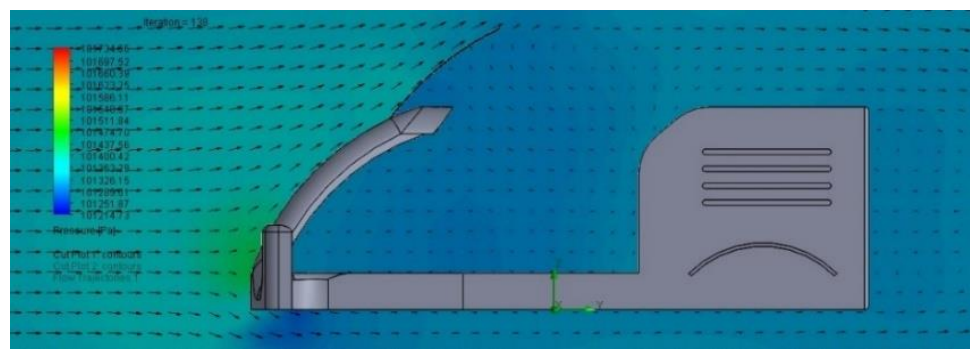

Figure 8. Distribution of pressure along the car body line concept 3 
Conceptual analysis of test car...

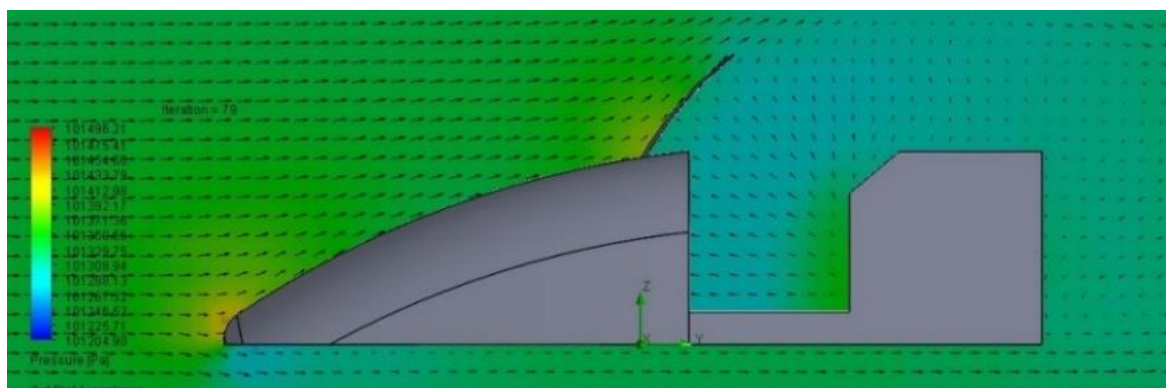

Figure 9. Distribution of pressure along the car body line concept 4

\section{Results}

Analysis of the simplified simulation of air flow around the test car body concept concerns the impact of the change of the shape of the front part of the vehicle on the distribution of pressure and on functional and aesthetic properties.

In concept 1 , a zone of the increased pressure, which is present in the front part, results from the geometric shape of the car body (Fig. 6). Visible reduction of pressure in the driver's space referred to the surrounding proves a more effective protection of a driver against air blows during driving. A built-up space for driver's legs considerably protects driver's body parts against outside impact. A visible zone of the increased pressure around the front part in concept 2 proves an increased head aerodynamic resistance (Fig. 7); however, reduced turbulences in the driver's space show the most effective protection against air blows that influence a driver. Ensuring aerodynamic shapes of the part of the vehicle that is the most exposed to air resistance results in the reduced space for a driver which negatively influences the operator's position during driving. In concept 3 (Fig. 8) the front part has an aesthetic function and improves driver's comfort by enabling him to maintain an unhindered position of legs during driving. In the symmetry plane of the vehicle, reduction of the head pressure value is observed. However, this structure is the weakest regarding protection of the driver's body against damage from the surrounding. Due to its geometry, the driver's body is more exposed to air blows. Concept 4 has protective functions of inside mechanisms and the driver's body parts maintaining at the same time aesthetic values. However, manoeuvring without obstacles is impeded in this concept. In all concepts, the use of a windshield protecting a driver, favourably influences the comfort of use of the vehicle since it limits air turbulence in the passenger space. Analysis of flow in the symmetry plane of the vehicle presents a local formation of aerodynamic resistance; however, the structure of the front part in concept 3 and 4 allows efficient reduction of the pressure increase.

\section{Conclusion}

The use of software for designing 3D models considerably facilitates engineering works at each stage of design. The conceptual analysis of the test car body in this article is a presentation of the simplified approach to designing, since no strength and modal analysis were included as an indispensable criterion of assessment and validity of taken decisions. Taking 
into consideration low vehicle speed, researches were focused on aesthetic and functional values and production possibilities of the Chair of Mechanics and Bases of Machines Design. Selection of the method, where the test car body will be manufactured depends on the technological nature and stiffness of the car body structure itself. Verification of the comfort of use during test and maintenance works may be carried out with the use of e.g. virtual reality technology. Previously built 3D models of particular concepts may be imported to the virtual reality and with the use of VR googles of a user inside a car body. Then, opinions of the surveyed persons may serve as instructions for manufacturing of the final car body.

\section{References}

Łach, A., Wyleżoł, M., Skarka, W. (2015). Główne aspekty modelowania nadwozia pojazdu konstruowanego na zawody Shell Eco-marathon, Mechanik, 2, 148-151.

Miąskowski, B., Miąskowski, W., Nalepa, K., Pietkiewicz, P. (2012). Analiza wytrzymałościowa ramy pojazdu testowego o napędzie niekonwencjonalnym. Mechanik, 7, 1051-1055.

Miąskowski, W., Nalepa K., Szczepańska, J., Trzcińska, A. (2017). Analiza koncepcyjna dostosowania pojazdu testowego do napędu z zasilaniem hybrydowym. Przegląd Mechaniczny, 6, 30-32.

Zieliński, A. (2008). Konstrukcja nadwozi samochodów osobowych i pochodnych. WKŁ Warszawa, Poland.

Orzełowski, S. (1969). Budowa podwozi i nadwozi samochodowych. WSiP Warszawa, Poland.

Budzik, G., Budzik, W., Cygnar, M., Janisz, K. (2009). Możliwości zastosowania szybkiego prototypowania w procesie projektowania i wytwarzania elementów pojazdów samochodowych. Problemy Eksploatacji, 1, 7-16.

Bilewski, A., Brewko, A., Bazgier, K., Tomiczek, M. (2013). „Projektowanie prototypu samochodu wyścigowego na zawody formula sae / formula student”, in Studencka Konferencja Naukowa „METODY KOMPUTEROWE - 2013”, R. Górski, M. Dziewoński, A. Poloczek (eds.), Gliwice Politechnika Śląska, 5-8.

Hinz, T., Lewkowicz, R. (2015). Wpływ kształtu elementów konstrukcyjnych nadwozi samochodowych wykonanych z tworzywa sztucznego na ich wytrzymałość. Mechanik, 5-6, 358-364.

Guilmineau, E., (2008). Computational study of flow around a simplified car body. Journal of Wind Engineering and Industrial Aerodynamics, 96, 1207-1217.

Song, K., Kang, S., Jun, S., Park, H., Kee, J., Kim, K., Lee, D. (2011). Effects on Aerodynamic Drag Reduction of a Passenger Car by Rear Body Shape Modifications. Transactions of the Korean Society of Automotive Engineers, 19, 137-145.

\section{ANALIZA KONCEPCYJNA KAROSERII POJAZDU TESTOWEGO Z WYKORZYSTANIEM SYSTEMÓW CAD}

Streszczenie. W artykule zaprezentowano założenia konstrukcyjne oraz analizę koncepcyjną nadwozia pojazdu testowego wyposażonego w hybrydowy układ napędowy. Pojazd testowy budowany jest przez studentów Wydziału Nauk Technicznych Uniwersytetu Warmińsko-Mazurskiego w Olsztynie. Prace poświęcone zaprojektowaniu i budowie nadwozia mają za zadanie zwiększenie bezpieczeństwa i poprawę estetyki budowanego pojazdu przy jednoczesnym zachowaniu jego funkcjonalności obsługowej i badawczej. W artykule przedstawiono uproszczoną analizę rozkładu ciśnienia wokół karoserii dla kilku zaproponowanych koncepcji oraz przedstawiono wybrane technologie wykonania nadwozia pojazdu testowego. W podsumowaniu omówiono wyniki symulacji komputerowej rozkładu ciśnienia oraz przedstawiono pozostałe aspekty oceny funkcjonalności nadwozia.

Słowa kluczowe: analiza, nadwozie, systemy CAD, pojazd testowy 